\title{
IMPACT OF EXTERNAL AND INTERNAL CIRCUMSTANCES ON FOOD SAFETY MANAGEMENT
}

\author{
A. Stoyanova* \\ Commodity Science Department, Faculty of Economics, University of Economics -Varna, Bulgaria
}

\begin{abstract}
PURPOSE: Preserving the health of consumers is the basis of adopted policies for food safety worldwide. The dynamic changes in regulatory requirements and the growing number of notifications about dangerous food products sold on the market are a prerequisite for introducing appropriate measures with which participants in the food chain can ensure and demonstrate food safety. The purpose of the present study is to assess the impact of external and internal issues that form the context of food-producing companies, using approaches based on risk-based thinking featuring in ISO 22000:2018. METHODS: The goal is achieved by identifying and analyzing the impact of external and internal circumstances on the surrounding environment. This study has applied the PESTLE and FMEA methods for identifying and assessing the circumstances as elements forming the company's context and objectives related to food safety management through proven expertise. RESULTS: On the basis of the analysis, factors of the environment which can raise concerns are defined and these can be followed by a company risk-and-opportunity assessment. CONCLUSIONS: Through the assessment performed, a basis is created for achieving better results and preventing negative consequences for the development of the company.
\end{abstract}

Key words: ISO 22000: 2018 standard, context, risk

\section{INTRODUCTION}

Over the last years we have witnessed the introduction of new technological practices in food manufacturing, the implementation of new automated systems in technical equipment, new technical solutions in registering process and product monitoring data, as well as the advent of new express methods for quality analysis and product safety. Regardless of the measures for improving production and control, we have observed a growing trend of food incidents. Serious concerns worldwide are evoked by notifications of dangerous foods supplied on the market, and these are prerequisites for seeking answers to questions like: Are the Food Safety Management Systems (FSMS), which have been introduced in practice, a sufficient condition for ensuring high levels of certainty regarding the ability of food industry to guarantee consumers health

\footnotetext{
*Correspondence to: Antoaneta Stoyanova, University of Economics - Varna, 77 Knyaz Boris I Blvd., 9002 Varna, Bulgaria, Phone: +359

895455844,E-mail: a.stoyanova@ue-varna.bg,
}

protection? The answer lies in the assumption that an improvement can be achieved only on the basis of familiar or safety-issues-adapted scientific approaches and methods, which in most cases are standardized and have been established as a generally recognized methodology and one incorporated into international food safety standards. The purpose of the present study is, by means of applying ISO 22000: 2018 standard approaches of risk-based thinking, to perform an assessment of the impact of the external and internal circumstances that form the context of food-producing companies.

Over the past years quality management and product safety have been perceived by many national and international organizations as an accurate and clearly defined approach for defining and fulfilling the requirements in all aspects. In this sense, safety management of the foodstuffs produced is in itself the application of certain methods of work and consumer relationships, which feature as requirements in international standards such as ISO 9001, ISO 22000, FSSC and other. 
As a term Food Safety Management System is deemed to comprise a set of programs and procedures, based on the good manufacturing practices and the principles of HACCP (Hazard Analysis Critical Control Point), the implementation of which generates conditions for independent control and ensuring food safety, or it is a system that conforms to the requirements of Codex Alimentarius or the Bulgarian state standard ISO 22000 (1). In other words, it can be stated that safety management, as a statutory system, deals with the specific peculiarities within the set of components that this system comprises. In the regulatory base there are requirements assigned to each and every food operator, which aim to assess the risk in a technological process based on analysis of the impacts of various hazards of biological, physical or chemical origin by applying the principles of the HACCP specification. Applying the HACCP specification comes as a preventive and not reactive approach to ensuring food safety and is based on good manufacturing and good hygiene practices, identification and assessment of hazards and thus guaranteeing safety. The dynamic change in the requirements of government regulatory bodies concerning control of diseases which result from the consumption of hazardous foods demands the adoption of entirely different approaches to the formulation and implementation of management strategies, compared to the conventional regulatory principles of the HACCP system (2). Classical approaches are being replaced by new attitudes to management, ones that can be described as process-based and are founded in the general principles of foodstuffs and riskbased thinking. While until recently food safety as a term was interpreted as "a concept, that foodstuffs will not cause the consumer harm as long as they have been prepared and/or consumed according to rules of proper usage”, in 2018 the ISO 22000:2018 standard further develops the terminology, so "food safety" is already defined as "certainty, that the food will not cause adverse effect on a consumer's health, as long as it has been prepared and consumed according to rules of proper usage" (3). We are right then to claim that the focus on ensuring food safety is not only on analysis and assessment of the hazards a particular product can present when consumed, but also a new and wider strategic view is taken of the interrelated character of numerous other objective circumstances that depend on policies worldwide. The transition is associated with a starting point from planning measures and activities to safeguard the safety concept as a preventive approach to objective evidence that the measures planned have been applied in practice efficiently and effectively enough, so as to guarantee absolute certainty the food consumed will not cause an adverse effect on consumer's health. Consequently, we have to conclude that the HACCP approach appears to be an insufficient condition for providing food safety. The dynamics of food safety management is viewed as a change from the stage of conventionally required criteria for food safety to a contemporary system of food safety management that complies with generally accepted management principles, associated with risk-based thinking (4).

\section{MATERIALS AND METHODS}

By applying the requirements of the BDS ISO 22000:2018 standard, opportunities will be identified for each firm to define the factors that can result in a deviation from expected results at every step of the company's processes, as well as the Food Safety Management System (FSMS) in general. Thus adequate and realistic preventive measures can be planned and applied in the management, execution and control of the particular process, in order to limit the negative consequences and fully use the available opportunities (5). Using the methodology incorporated in the BDS EN ISO 22000:2018 standard makes it possible to identify the degree of impact of all factors functioning as potential or real hazards for the product and the environment in order to respond to the needs of all the participants in the food chain (operators and consumers) as well as take real actions connected with raising the level of biological and chemical safety (6). In many cases a mere examination of the hazards but negligence of the risks stemming from external and internal circumstances justify the application of a more complex approach in developing a FSMS rather than seeking compliance with established statutory requirements. In other words, it is only through an approach based on risk-management principles that a complex evaluation of safety at the management level of the organization can be made and then, at the operating level the degree of influence of the hazards in the process of manufacturing and product placement can be assessed (7). Planning these activities is based on research into scientific opinions in Epidemiology of Foodborne 
Diseases; good practices in reducing risks associated with products and processes, risk design and risk analysis (organizational and operating risks) as early as the product design and product development stage (8). It can be inferred that planning the necessary conditions and resources to ensure the implementation of production and control processes at each technological step up to the stage of product realization is the main factor in providing foodstuffs safety (9). According to Codex Alimentarius risk is defined as ,function of the probability of an adverse effect on health and the gravity of this effect, as a result of food hazard/s" (10). Accounting for the probability of adverse effect in risk assessment considers the number of adverse results (e.g diseases, hospitalizations and deaths) related to a given hazard in multiple foodstuffs (11). Adverse impacts can stem from the influence of various factors defining every company's context. As a term, context is regarded as a combination of internal and external factors and conditions that can influence the approach of the organization towards its products, services, investment and stakeholders. This notion is also covered by phrases like 'business environment, 'organization environment' and 'an organization ecosystem'. Context (the external and internal conditions) is connected with the results of quality management or safety by performing an analysis of political, economic, socio-cultural, technological, legislative and ecological factors of the environment through the application of the PESTLE method. Identifying the circumstances is a guarantee that the external and internal parameters necessary to management have been established. In this way the field of application of risk criteria pertaining to the process of risk assessment is defined.

Through survey and evaluation of the degree of external and internal factors impact, every manufacturer can quantitatively assess to what extent he/she is dependent on the external environment and how this environment influences his/her activity. Context is a new point as a requirement in the ISO 22000:2018 standard and already raises the food safety management systems to an entirely different level - not as an isolated independent management, but rather as a social and economic subject on a macro scale. That is to say, management of the particular company's activity is examined in view of the application of adequate and practical preventive measures, designed to limit negative implications and make full use of the opportunities available, by risk assessment (12). According to the latest requirements, manufacturers' focus on safety is not orientated only towards the target group of consumers, but to all stakeholders as well. Internal and external circumstances can change and should therefore be monitored and reviewed regularly. This leads to defining the key elements in the scope of FSMS, in particular safety policies, activity planning, defining objectives about controlling risks and minimizing them and identifying the real capacities. The key factors that are a subject of analysis of the macro environment (the external environment) have been identified by means of the so called PESTLE expert analysis method. PESTLE analysis is an instrument for long-term strategic planning and covers a period of 3-5 years ahead, with annual updates of information.

\section{IDENTIFICATION AND ANALYSIS OF EXTERNAL CIRCUMSTANCES: P (political factors) - factors of the political} and legal environment. In the analysis of the political environment for the food industry the following significant elements appear: Staying power of the political system and the current government. E (economic factors) factors of the economic conditions on the market. Analysis of this group of factors results in identification of the state of the economy/ the market where the company operates under circumstances of growing globalization in food trade, intensification of agriculture, farming subsidies, and changes in the amount of arable land, the level of development of the bank sector and the EU framework programs for funding business enterprises, etc.. S (socio-cultural) - the social and cultural factors of the market. The analysis of this group of factors describes the impact of demographic migration of the population, ethnic origin, educational level of local population, its age and social categorization (concentration and polarization of population in large cities and urbanized lifestyles - consumption of processed food and ready meals prepared in the public catering sector). $\mathbf{T}$ (technological factors) factors that characterize the technological advancements in the industry - new technological practices in agriculture and foodstuff manufacturing ( these lead to changes in the exposition to risk factors, owing to the lack of accumulated data on 
their impacts on foods). L (legislative factors) - These are identified and carefully monitored for each change in legislation and the possible impact the particular change may have on the food sector. E (ecological factors) - These factors refer to the impact of the environment on the company. With the growing role of corporate responsibility for sustainability, this element is getting increasingly important and is associated with pollution caused by excessive use of plant protection chemicals (PPC) for agricultural crops. Climate changes resulting in changes of amounts of rainfall and rising temperatures, which in turn lead to growing populations of certain biological species and changes of the pattern of vegetation of various agricultural crops (13). The increase in the number of natural disasters, reduced yields of raw materials owing to climate changes (14). Climate changes will lead to increased intensity of spreading diseases affecting people and animals as a result of unpredictable changes in microorganisms and the creation of ecological niches; Spontaneous genetic mutations and genetic transfer of microorganisms connected with the evolution of intermediary host organisms in cases of infections and invasions (15). External circumstances are founded in circumstances beyond the control of the organization, but they are characterized by concrete details, stemming from the regulatory changes, the policies applied, and the environmental changes and their influence upon stakeholders, as well as other aspects typical for the process of risk management, and particularly risk minimization. Unlike the external circumstances, the internal ones are the internal environment in which the organization strives to achieve its goals. Internal circumstances are mostly found within the organization, which fact can influence the way the organization manages its activity to ensure the practical application of the documented rules of the food safety management system.

Defining and analyzing internal circumstances - Internal factors that impact the company activities are defined by experts. Consequently, within the group of internal factors influencing food safety a set of phenomena can be identified, as well as conditions which impact food safety throughout the technological stages of manufacturing. The degree of their influence can be regarded as a prerequisite for risk occurrence concerning processes or risk concerning the identified dangers in the technological process connected with product realization of items that have already been produced. Internal factors are grouped and divided, as follows: Effectiveness of applied policies - Lack of knowledge and competence on the part of company owners about applying scientific approaches to ensure safety; Strategy for reducing residual amounts of plant protection chemicals for carrying out disinfection, desinsection and deratization (DDD) activities; Strategies and policies for informing consumers. Qualification and competence of staff - Reduced number of people employed in agriculture and food sector; Inadequate storage of raw materials and failure to comply with optimum storage requirements; contamination of food by staff or cross-contamination of the raw material finished products flow; Lack of verified health status of personnel directly involved in food manipulation. Product safety - in terms of consumer preferences and changes in regulatory requirements - increased use of anti- microbe instruments/ consequently resistance to foodborne diseases; inconsistent quality of agricultural materials for food production. Product presentation-Increased use of pesticides while growing the raw materials and compromising the finished product safety. Pricing policy - food industry is heavily dependent on fluctuations in the prices of agricultural and animal products and the trend of business reorientation, so that food manufacturers bear the larger burden of volatile prices and manufacturing conditions, so planning and forecasting of the business should evolve on the basis of risk management.

The methodology of PESTLE analysis can be applied through the consistent application of the following steps:

Step 1: Identifying factors for analysis - all internal and external factors described above are presented in Table 1 PESTLE analysis of the external environment factors and Table 2 Analysis of the internal environment. Factors which in no way influence the activity of the company are not included in the table. The list of factors can be amended (by adding new ones or deleting any of those that have already been identified) according to the circumstances of the surrounding environment and according to the particular activity and position of each of the food chain operators. 
Step 2: Identifying the degree of impact of factors - at this stage each factor's degree of influence on the activity of the organization is identified. Evaluations are performed by selected experts, following an evaluation scale of 1 to 3 , where 1 stands for the lowest impact, and 3 - for a very high impact. Evaluation is individual, but is tied up with the expert opinion of the evaluators (column 3 with five sub columns) in Table.1 PESTLE analysis of the external environment factors and Table 2 Analysis of internal environment factors.

Step 3: Estimating the probability of factor change - this illustrates the probability of changes occurring in the factors of external/internal environment. Evaluation takes place on a scale of 1 to 5 , where 1 stands for minimum probability and 5- maximum probability. Evaluation is performed by a panel of 5 experts with extensive experience in the food industry, good knowledge of modern technologies and the regulatory base and serious background in the management of various hazards, who are able to estimate how a particular factor impacts transfer of hazards and presents a risk for food safety. After entering the evaluations of the five experts in column (4) of Table 1 PESTLE analysis of external environment factors and Table 2 Analysis of internal environment factors the average mean of the probability of factor change is calculated.
Step 4: Estimating the real significance of factors - at this stage the real significance of each factor is calculated. Real significance is calculated as a probability of factor change by weight relative to the strength of impact of this factor on company activity (column 5) of Table 1 and Table 2.

The higher the real significance of a particular factor, the more attention and efforts should be put in reducing the negative impact of the factor on the company's business.

\section{RESULTS}

The team of experts has identified how a positive or negative change in external or internal factor impact can affect the activity of the company. The results of the performed analysis of the external factors are presented in Table 1 "PESTLE analysis of external environment factors" and the results of the performed analysis of internal circumstances are presented in Table 2 "Analysis of the internal environment factors". From the data in Table 1 and Table 2 quantitative assessments can be made about the significance of key components of each of the identified external and internal factors for the company. For each factor the degree of impact on company or industry is pointed, while the factor is subjected to an evaluation in order to identify the degree of risk the factors bring to the company or the FSMS in general.

Table 1. Analysis of external environment factors

\begin{tabular}{|c|c|c|c|c|c|c|c|c|c|}
\hline \multirow{3}{*}{ № } & 1 & 2 & & & 3 & & & 4 & 5 \\
\hline & \multirow[t]{2}{*}{ Description of factor } & \multirow[t]{2}{*}{$\begin{array}{l}\text { Factor } \\
\text { impact }\end{array}$} & \multicolumn{5}{|c|}{$\begin{array}{l}\text { Expert assessment of } \\
\text { evaluators on } \\
\text { probability of factor } \\
\text { change }\end{array}$} & \multirow{2}{*}{$\begin{array}{c}\text { Average mean } \\
\text { estimate of } \\
\text { probability of } \\
\text { change }\end{array}$} & \multirow[t]{2}{*}{$\begin{array}{l}\text { Assessment of } \\
\text { factor real } \\
\text { significance }\end{array}$} \\
\hline & & & 1 & 2 & 3 & 4 & 5 & & \\
\hline \multicolumn{10}{|c|}{ POLITICAL FACTORS (P) } \\
\hline & $\begin{array}{l}\text { Staying power of political authority and present } \\
\text { government }\end{array}$ & 2 & 5 & 5 & 5 & 5 & 5 & 5,0 & 0,10 \\
\hline & Bureaucracy and level of corruption & 2 & 1 & 3 & 3 & 3 & 3 & 2,6 & 0,05 \\
\hline & Tax policy- duties and tariffs & 1 & 2 & 1 & 1 & 3 & 3 & 2,0 & 0,02 \\
\hline & $\begin{array}{l}\text { Communication betweeen structural units of } \\
\text { executive bodies for integrated food control }\end{array}$ & 3 & 5 & 4 & 4 & 5 & 4 & 4,4 & 0,13 \\
\hline & $\begin{array}{l}\text { Trends in food sector regulation - protectionism } \\
\text { for nationally produced food }\end{array}$ & 2 & 1 & 3 & 2 & 3 & 3 & 2,4 & 0,05 \\
\hline & $\begin{array}{l}\text { Expansion of international trade - preferences } \\
\text { for import; trade policy on raw materials }\end{array}$ & 2 & 2 & 2 & 2 & 3 & 2 & 2,2 & 0,04 \\
\hline & $\begin{array}{l}\text { Strive for protectionism in the sector; } \\
\text { availability of monopolistic companies in the } \\
\text { sector }\end{array}$ & 2 & 2 & 1 & 1 & 3 & 2 & 1,8 & 0,03 \\
\hline & $\begin{array}{l}\text { Subsidies in public healthcare to protect } \\
\text { population's health and inform consumers }\end{array}$ & 3 & 2 & 2 & 1 & 2 & 2 & 1,8 & 0,05 \\
\hline
\end{tabular}


STOYANOVA A.

\begin{tabular}{|c|c|c|c|c|c|c|c|c|}
\hline $9 \mid \begin{array}{l}\text { Probability of warfare breaking out in the } \\
\text { country, terrorism, influx of refugees }\end{array}$ & 1 & 2 & 2 & 2 & 2 & 2 & 2,0 & 0,02 \\
\hline $10 \mid \begin{array}{l}\begin{array}{l}\text { Presence of foreign military forces and tense } \\
\text { relationships with neighbouring countries }\end{array} \\
\end{array}$ & 1 & 1 & 2 & 2 & 1 & 1 & 1,4 & 0,01 \\
\hline \multicolumn{9}{|l|}{ ECONOMIC FACTORS } \\
\hline 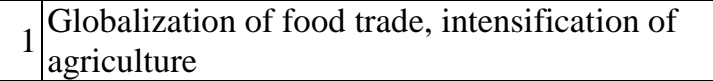 & 2 & 5 & 5 & 5 & 5 & 5 & 5,0 & 0,10 \\
\hline $\begin{array}{l}\text { Inflation rate, exchange rates and interest rate } \\
\text { associated with imports of raw materials and } \\
\text { additional components }\end{array}$ & 1 & 5 & 4 & 4 & 3 & 4 & 4,0 & 0,04 \\
\hline $3 \begin{array}{l}\text { Unemployment rate, size of wage, conditions of } \\
\text { work }\end{array}$ & 2 & 1 & 2 & 3 & 1 & 1 & 1,6 & 0,03 \\
\hline $4 \begin{array}{l}\text { Level of development of entrepreneurship and } \\
\text { the business environment; imported versus } \\
\text { nationally poduced foods ratio }\end{array}$ & 3 & 3 & 3 & 3 & 3 & 3 & 3,0 & 0,09 \\
\hline $5 \begin{array}{l}\text { Monetary and fiscal policy of the country; } \\
\text { subsidies for staple foods }\end{array}$ & 2 & 2 & 2 & 2 & 2 & 3 & 2,2 & 0,04 \\
\hline $6 \begin{array}{l}\text { Economic regulations of registration and } \\
\text { permission to use plant protection chemicals }\end{array}$ & 2 & 2 & 2 & 2 & 2 & 2 & 2,0 & 0,04 \\
\hline $7 \begin{array}{l}\text { Level of development of bank sphere and EU } \\
\text { framework programs for funding businesses }\end{array}$ & 2 & 3 & 2 & 2 & 3 & 2 & 2,4 & 0,05 \\
\hline \multicolumn{9}{|l|}{ SOCIO-CULTURAL FACTORS (S) } \\
\hline 1) Level of public healthcare and education & 3 & 3 & 3 & 3 & 3 & 2 & 2,8 & 0,08 \\
\hline $2 \mid \begin{array}{l}\text { Attitudes to labour, careers, social benefits and } \\
\text { retirement }\end{array}$ & 1 & 5 & 5 & 5 & 5 & 5 & 5,0 & 0,05 \\
\hline 3 Requirements about product and service quality & 2 & 3 & 4 & 5 & 5 & 4 & 4,2 & 0,08 \\
\hline $4 \mid \begin{array}{l}\text { Local population education, age- and- social } \\
\text { categorization }\end{array}$ & 4 & 3 & 4 & 3 & 3 & 4 & 3,4 & 0,13 \\
\hline 5 L $\begin{array}{l}\text { ifestyle ( urbanization) and consumer habits } \\
\text { concerning ready-made meals and processed } \\
\text { food }\end{array}$ & 3 & 4 & 5 & 5 & 5 & 5 & 4,8 & 0,14 \\
\hline 6 State of religious and other beliefs & 1 & 1 & 1 & 1 & 2 & 2 & 1,4 & 0,01 \\
\hline $7 \mid \begin{array}{l}\text { Population growth rates and ageing of large } \\
\text { target groups ( raises in the nubers of elderly, } \\
\text { chronically ill, immunosupressed) }\end{array}$ & 3 & 3 & 4 & 4 & 3 & 3 & 3,4 & 0,10 \\
\hline 8 |l $\begin{array}{l}\text { Level of migration and attitudes towards } \\
\text { immigration }\end{array}$ & 2 & 3 & 3 & 3 & 3 & 3 & 3,0 & 0,06 \\
\hline $9 \begin{array}{l}\text { Gender - and-age structure of population, } \\
\text { average life expectancy }\end{array}$ & 3 & 4 & 4 & 4 & 4 & 3 & 3,8 & 0,11 \\
\hline $10 \begin{array}{l}\text { Social division of population,minorities, poor } \\
\text { knowledge of content and physiological impact } \\
\text { of foods }\end{array}$ & 3 & 3 & 3 & 3 & 3 & 3 & 3,0 & 0,09 \\
\hline \multicolumn{9}{|l|}{ TECHNOLOGICAL FACTORS (T) } \\
\hline $1 \mid \begin{array}{l}\text { Level of innovations and technological } \\
\text { development of the industry }\end{array}$ & 3 & 3 & 4 & 3 & 1 & 4 & 3,0 & 0,09 \\
\hline $2 \mid \begin{array}{l}\text { Research and development costs in view of } \\
\text { emerging hazards }\end{array}$ & 3 & 4 & 5 & 5 & 4 & 5 & 4,6 & 0,13 \\
\hline $3 \mid \begin{array}{l}\text { Control and monitoring of degree of } \\
\text { contamination of input materials }\end{array}$ & 4 & 3 & 4 & 5 & 4 & 4 & 4,0 & 0,15 \\
\hline $4 \mid \begin{array}{l}\text { Level and methods of control about } \\
\text { identification and traceability of batches of } \\
\text { finished products }\end{array}$ & 2 & 2 & 2 & 2 & 2 & 3 & 2,2 & 0,04 \\
\hline 5 |l $\begin{array}{l}\text { Access to the latest technologies in food } \\
\text { manufacturing }\end{array}$ & 2 & 3 & 3 & 3 & 3 & 2 & 2,8 & 0,05 \\
\hline 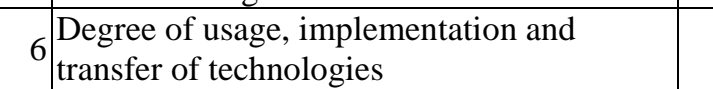 & 3 & 3 & 4 & 4 & 2 & 3 & 3,2 & 0,09 \\
\hline \multicolumn{9}{|l|}{ LEGISLATIVE FACTORS (L) } \\
\hline $1 \begin{array}{l}\text { Anti-monopole, tax and labour legislation; } \\
\text { Bioterrorism and deliberate release of } \\
\text { hazardous microorganisms }\end{array}$ & 3 & 3 & 2 & 3 & 2 & 2 & 2,4 & 0,07 \\
\hline
\end{tabular}


STOYANOVA A.

\begin{tabular}{|c|c|c|c|c|c|c|c|c|}
\hline 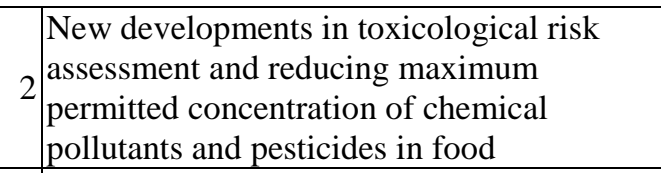 & 4 & 5 & 5 & 5 & 5 & 5 & 5,0 & 0,19 \\
\hline $3 \mid \begin{array}{l}\text { Reducing requirements to to food operators } \\
\text { as to statutory sample tests - greater } \\
\text { responsibility/freedom for food } \\
\text { manufacturers }\end{array}$ & 4 & 4 & 4 & 4 & 4 & 4 & 4,0 & 0,15 \\
\hline $4 \begin{array}{l}\text { Current legislation and changes therein, } \\
\text { regulatory environment, harmonization }\end{array}$ & 3 & 3 & 3 & 3 & 1 & 3 & 2,6 & 0,08 \\
\hline \multicolumn{9}{|l|}{ ECOLOGICAL FACTORS } \\
\hline 1 Climate changes & 5 & 4 & 4 & 4 & 4 & 4 & 4,0 & 0,19 \\
\hline \begin{tabular}{l|l}
2 & Falling yields of raw materials
\end{tabular} & 2 & 3 & 3 & 3 & 3 & 3 & 3,0 & 0,06 \\
\hline $3 \begin{array}{l}\text { Pollution of soil and raw materials resulting } \\
\text { from excessive use of plant protection } \\
\text { chemicals (PPC) in farming }\end{array}$ & 3 & 3 & 3 & 4 & 3 & 4 & 3,4 & 0,10 \\
\hline $4 \mid \begin{array}{l}\text { Higher intensity of spreading diseases to } \\
\text { people and animals as a result of } \\
\text { unpredicted changes in microorganisms and } \\
\text { creation of ecological niches }\end{array}$ & 4 & 4 & 4 & 4 & 4 & 4 & 4,0 & 0,15 \\
\hline 5 Demands for sustainable ecosystem & 1 & 2 & 2 & 2 & 1 & 3 & 2,0 & 0,02 \\
\hline
\end{tabular}

PESTLE analysis of external environment

factors

Table 2. Analysis of internal environment factors

\begin{tabular}{|c|c|c|c|c|c|c|c|c|c|}
\hline \multirow{3}{*}{ № } & \multirow{3}{*}{ Description of factor } & \multirow{3}{*}{$\begin{array}{l}\text { factor } \\
\text { impact }\end{array}$} & \multirow{2}{*}{\multicolumn{5}{|c|}{$\begin{array}{c}3 \\
\text { Expert assessment } \\
\text { by evaluators on } \\
\text { probability of } \\
\text { factor change }\end{array}$}} & \multirow{3}{*}{$\begin{array}{c}4 \\
\begin{array}{c}\text { Average } \\
\text { mean }\end{array} \\
\text { estimate of } \\
\text { probability of } \\
\text { change }\end{array}$} & \multirow{3}{*}{$\begin{array}{l}\text { Assessment of } \\
\text { factor real } \\
\text { significance }\end{array}$} \\
\hline & & & & & & & & & \\
\hline & & & 1 & 2 & 3 & 4 & 5 & & \\
\hline \multicolumn{10}{|c|}{ Effectiveness of applied policies } \\
\hline 1 & $\begin{array}{l}\text { Financial policy, attracting capital to } \\
\text { reach new markets }\end{array}$ & 1 & 5 & 5 & 5 & 5 & 5 & 5,0 & 0,07 \\
\hline 2 & $\begin{array}{l}\text { Investment policy in core activity in } \\
\text { order to provide safe raw materials for } \\
\text { production }\end{array}$ & 2 & 3 & 5 & 5 & 5 & 5 & 4,6 & 0,14 \\
\hline 3 & $\begin{array}{l}\text { Implementation of innovative methods } \\
\text { for automating production }\end{array}$ & 1 & 2 & 1 & 1 & 3 & 3 & 2,0 & 0,03 \\
\hline 4 & $\begin{array}{l}\text { Strategic direction towards developing } \\
\text { new products - inserting additives }\end{array}$ & 1 & 5 & 4 & 3 & 5 & 4 & 4,2 & 0,06 \\
\hline 5 & Policies on informing consumers & 2 & 1 & 3 & 2 & 3 & 3 & 2,4 & 0,07 \\
\hline 6 & $\begin{array}{l}\text { Strategy of reducing residual amounts of } \\
\text { PPC in performing DDD activities }\end{array}$ & 1 & 2 & 1 & 1 & 3 & 1 & 1,6 & 0,02 \\
\hline \multicolumn{10}{|c|}{ Qualification and competence } \\
\hline 1 & $\begin{array}{l}\text { Qualification and competence of } \\
\text { managerial staff and those emplyed in } \\
\text { manufacturing }\end{array}$ & 2 & 5 & 5 & 5 & 5 & 5 & 5,0 & 0,15 \\
\hline 2 & $\begin{array}{l}\text { Changes inmanagement on organization } \\
\text { of manufacturing - introduction of } \\
\text { automated systems }\end{array}$ & 3 & 5 & 4 & 4 & 3 & 4 & 4,0 & 0,18 \\
\hline 3 & $\begin{array}{l}\text { Shortage or surpluss of managerial staff, } \\
\text { staff turnover }\end{array}$ & 2 & 1 & 2 & 3 & 1 & 1 & 1,6 & 0,05 \\
\hline 4 & $\begin{array}{l}\text { Efficiency and interchangeability of staff } \\
\text { concerning materials control - products }\end{array}$ & 1 & 1 & 2 & 3 & 1 & 1 & 1,6 & 0,02 \\
\hline
\end{tabular}


STOYANOVA A.

\begin{tabular}{|c|c|c|c|c|c|c|c|c|c|}
\hline 5 & $\begin{array}{l}\text { Inadequate storage of raw materials and } \\
\text { failure to obey rules for optimum storage }\end{array}$ & 2 & 5 & 5 & 3 & 2 & 5 & 4,0 & 0,12 \\
\hline 6 & $\begin{array}{l}\text { Lack of verified health status for staff } \\
\text { directly manipulating foods }\end{array}$ & 2 & 3 & 3 & 3 & 3 & 3 & 3,0 & 0,09 \\
\hline 7 & $\begin{array}{l}\text { Failure to execute adopted practices of } \\
\text { monitoring and product- and- process } \\
\text { control }\end{array}$ & 3 & 3 & 3 & 3 & 3 & 3 & 3,0 & 0,13 \\
\hline \multicolumn{10}{|c|}{$\begin{array}{l}\text { Pricing policy } \\
\end{array}$} \\
\hline 1 & $\begin{array}{l}\text { Level of knowledge of the market. } \\
\text { Market share compared to nearest } \\
\text { competitors }\end{array}$ & 3 & 3 & 2 & 3 & 2 & 2 & 2,4 & 0,11 \\
\hline 2 & $\begin{array}{l}\text { Changes in prices of agricultural or } \\
\text { animal raw materials }\end{array}$ & 4 & 5 & 5 & 5 & 5 & 5 & 5,0 & 0,30 \\
\hline 3 & Ability to set higher prices & 2 & 3 & 4 & 5 & 5 & 4 & 4,2 & 0,13 \\
\hline 4 & Price sensitivity of target groups & 3 & 3 & 3 & 3 & 3 & 4 & 3,2 & 0,14 \\
\hline 5 & Effective pricing & 2 & 2 & 3 & 3 & 3 & 3 & 2,8 & 0,08 \\
\hline 6 & $\begin{array}{l}\text { Tool set to use in cases of delayed } \\
\text { payments by clients }\end{array}$ & 2 & 2 & 2 & 2 & 2 & 2 & 2,0 & 0,06 \\
\hline 7 & Product withdrawal costs & 2 & 3 & 4 & 3 & 2 & 2 & 2,8 & 0,08 \\
\hline \multicolumn{10}{|c|}{ Ready foods safety } \\
\hline 1 & $\begin{array}{l}\text { Increased usage of antimicrobe } \\
\text { substances/consequently resistance to } \\
\text { foodborne diseases }\end{array}$ & 4 & 3 & 3 & 3 & 3 & 3 & 3,0 & 0,18 \\
\hline 2 & $\begin{array}{l}\text { Packaging - associated with migration of } \\
\text { intelligent materials during contact with } \\
\text { foods }\end{array}$ & 3 & 2 & 2 & 2 & 2 & 2 & 2,0 & 0,09 \\
\hline 3 & $\begin{array}{l}\text { Complience of finished products with } \\
\text { the attached technological } \\
\text { documentation }\end{array}$ & 3 & 3 & 4 & 5 & 2 & 4 & 3,6 & 0,16 \\
\hline 4 & $\begin{array}{l}\text { Inconsistence of quality of agricultural } \\
\text { raw materials for food manufacturing }\end{array}$ & 5 & 4 & 4 & 4 & 4 & 4 & 4,0 & 0,30 \\
\hline 5 & $\begin{array}{l}\text { Complience of quality with statutory } \\
\text { regulations on food safety }\end{array}$ & 5 & 5 & 5 & 5 & 5 & 5 & 5,0 & 0,37 \\
\hline \multicolumn{10}{|c|}{ Product allocation and product presentation } \\
\hline 1 & Width of product range & 1 & 2 & 2 & 2 & 2 & 2 & 2,0 & 0,03 \\
\hline 2 & $\begin{array}{l}\text { Notifications of product deficits or } \\
\text { surplusses }\end{array}$ & 1 & 3 & 3 & 2 & 3 & 2 & 2,6 & 0,04 \\
\hline 3 & Fast liquidity and market realization & 2 & 2 & 2 & 2 & 2 & 2 & 2,0 & 0,06 \\
\hline 4 & $\begin{array}{l}\text { Opportunity of achieving sales amounts } \\
\text { and sales volumes for large customers }\end{array}$ & 2 & 3 & 3 & 2 & 3 & 2 & 2,6 & 0,08 \\
\hline
\end{tabular}

\section{Analysis of internal environment factors}

From the external factors: Political factors intersect Legislative factors in direct dependence on the impact of Ecological and Technological ones. The main difference, however, is that political factors are directed by government politics, while legislative ones have to be complied with, as they have been an object of a legislation approved by many governments. It can be pointed out that climate changes are among the most substantial factors, as they are related to a lasting increase in temperatures. They are a prerequisite for continuous dynamics in the population of biological agents that present a significant safety risk. This in turn becomes a stimulus for many government agencies to develop policies and seek legislative solutions through new scientifically well-grounded methods in toxicological risk assessment and reducing the maximum permissible concentrations of chemical pollutants and pesticides in foods. Therefore, communication between structural units of the executive power aimed at integrated food control is one of the most essential elements of impact. Through communication and coordination a unified approach can be applied to identifying new diseases in plants/animals, as the latter are potential contaminants of foods at a next stage. The assessment is the foundation for planning activities that could alleviate the factor's negative impact or, in the opposite case, make 
maximum use of the positive impact on the activity of the company and the business. In regard to internal factors, it is obvious from Table 2 that one of the most significant strategic aspects is the investment policy in the core activity of providing homogeneous and safe basic materials for production, introducing new automated technological production methods and modern methods of control of products and processes, as well as a continuous improvement of staff competence in order to guarantee the supply of safe processed foods on the market.

\section{CONCLUSION}

The identified external and internal circumstances can present risks (threats) and/or opportunities in relation to food safety. Therefore, they can be brought under control through planned activities. In a dynamic and rapidly changing environment identifying and evaluating the factors of the external and internal environment can also change for different periods of time and this in turn is related with the dynamics of adopted and established company goals concerning product safety and the functioning of the food safety management system in general. These factors may be viewed as prerequisites for hazards to reach health-threatening level. The emergence of adverse events or permission of intensive impact of the above mentioned factors during production are the reason for the appearance of inconsistencies regarding safety. Many organizations are actively looking for approaches which could help them improve their own processes safety, avoid, eliminate or minimize real and potential accidents and thus make sure that safety goals are achieved.

\section{REFERENCES}

1. BDS EN ISO 22000:2005 Food safety management systems - Requirements for any organization in the food chain/ BIS. Sofia, 2006

2. BDS EN ISO 22000:2018 Food safety management systems. Requirements for any organization in the food chain// BIS. Sofia, 2018

3. BDS EN ISO 9000:2015 - Quality management systems - Fundamentals and vocabulary // BIS. Sofia, 2015.
4. BDS EN ISO 31000:2018 - Risk management - Guidelines. // BIS. Sofia, 2018.

5. CAC/GL 53-2003, Guidelines on the judgement of equivalence of sanitary measures associated with food inspection and certification systems

6. Larsen, John; Karin , Kristiane; Beltoft , Vibe; Lund , Pia; Binderup, Mona-Lise ; Frandsen, Henrik, EFSA Panel on Food Contact Materials, Enzymes, Flavourings and Processing Aids (CEF); Scientific Opinion on Flavouring Group Evaluation 20, Revision 3, European Food Safety Authority, 2011.

7. Mallon, C. A.; Van Elsas, J. D.; Salles, J. F., Microbial invasions: the process, patterns, and mechanisms, Trends in microbiology, 2015, p.719-729

8. Taylor, M. R.; Hoffmann, S. A., Redesigning food safety, Issues in Science and Technology, 2001, p. 26-30.

9. Hansen, J., Lotte, H., Lynn, Fre., Robinson, P., Beyond the knowledge deficit: recent research into lay and expert attitudes to food risks, Appetite, 2003, p. 111-121

10.EFSA, Emerging Risks Exchange Network, Technical report of EFSA prepared by the ESCO WG on Emerging Risks. EFSA Technical Report , 2009, 224, 1-34

11.EFSA Panel on Biological Hazards (BIOHAZ): Scientific Opinion on the development of a risk ranking framework on biological hazards. EFSA J 2012, 10:2724.

12.BDS EN ISO 31010:2010 - Risk management - Risk assessment techniques.// BIS. Sofia, 2010.

13.Porter, J.R. \& Semenov, M.A., Crop responses to climatic variation. Philosophical Transacations of the Royal Society B: Biological Sciences, 2005, 360, 2021-2035.

14.Leff, B., Ramankutty, N. \& Foley, J. 2004. Geographic distribution of major crops across the world. Article No. GB1009 in Global Biogeochemical Cycles, 18, (1).

15.Tirado MC., Meerman J., The impact of climate change and bioenergy on nutrition. In: Thompson B, Cohen MJ (eds). The impact of climate change and bioenergy on nutrition. Springer Netherlands, Dordrecht, 2012, pp. 43-60. 